\title{
Moral Development of Children during the COVID-19 Pandemic
}

\author{
Perkembangan Moral Anak di Masa Pandemi COVID-19
}

\author{
Nia Anggri Noveni ${ }^{1}$, Bagus Rizqy Yudhya Putra ${ }^{2}$, Mellyna Putri Utami ${ }^{3}$, Putri Rahmawati ${ }^{4}$, Maharani \\ Susilowati $^{5}$, Aidul Akbar Diawara ${ }^{6}$, Anisha Alyadini ${ }^{7}$ \\ 1, 2, 3, 4, 5, 6, 7 Universitas Muhammadiyah Purwokerto, Purwokerto, Indonesia
}

\begin{abstract}
ARTICLE INFO
Article history:

DOI:

$\underline{10.30595 / p s s h . v 2 i .96}$

Submitted: July 27, 2021

Accepted: Aug 28, 2021

Published: Sept 24, 2021

ABSTRACT

The Covid-19 pandemic requires people to implement social distancing (activity restrictions) to anticipate the spread of Covid-19. This study aims to determine the moral development of children during the Covid-19 pandemic and to determine the role of adults in the formation of children's moral development during the pandemic. The subjects of this study amounted to 104 people who are parents or siblings who are in the same house with children in Pandemic. This study uses a quantitative approach with survey methods and data collection techniques used are questionnaires through Google Form. The survey results show that only $75 \%$ of parents or siblings of children make regulations related to social distancing, while $25 \%$ do not make regulations related to social distancing. Basically, the attitude shown by adults will have a big influence on the children moral's reasoning about social distancing. In addition, children aged 0-5 years have not obeyed the rules made, but children aged above 5-10 years will begin to obey the rules. Meanwhile, at the age of 9 to more than 10 years, children begin to consider the purpose and consequences of social distancing rules that have been made by adults.

Keywords:

Child Moral Development,
\end{abstract} COVID-19, Pandemic, Piaget's Moral

Development, Social

Distance

This work is licensed under a Creative Commons Attribution 4.0 International License.

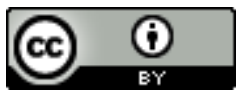

Corresponding Author:

Nia Anggri Noveni

Universitas Muhammadiyah Purwokerto, Indonesia

Email: niaanggrinoveni@ump.ac.id

\section{INTRODUCTION}

At the beginning of 2020 there was a COVID-19 pandemic that spread throughout the world. Currently the world is being hit by the Covid-19 pandemic, where from day to day there is a very large increase in positive cases and it is difficult to control. Covid-19 is an infectious disease caused by a type of corona virus that was only discovered at the end of 2019. The number of additional Covid-19 cases in Indonesia can be said to be very high every day, starting from May 13. The Central Java region experienced an increase in positive cases of Covid-19 as many as 480 people, while West Java as many as 400 people.

The pandemic situation has forced the government to issue policies related to social distancing rules or efforts to maintain distance and avoid crowds based on the rules (Minister of Health Regulation No. 9 of 2020) in order to reduce the spread of the COVID-19 virus. People from parents, adults to children need to understand and implement the policies that have been issued by the Indonesian government regarding social distancing. Children also need to understand the effects of social distancing regulations, such as school activities being closed, being replaced by an online system, reducing crowding activities in public places, including religious activities.

Childhood is a time when individuals need exploration of the surrounding environment such as family, school, and society. However, during this pandemic, children's exploration can be done from inside the house. This was done because adjustments to government programs related to the spread of Covid-19 by maintaining physical distance and social distancing were restrictions on community activities carried out by all people in certain areas suspected of being infected with the disease.

This social restriction aims to prevent the spread of the disease from spreading further in the area. Social restrictions are also carried out by reducing social interaction and staying at home and limiting the use of public transportation. Social restrictions in this case are physical distancing, such as, it is forbidden to be close and make 
physical contact with other people and maintain a minimum distance of about 1-2 meters, do not shake hands, do not hug or kiss, avoid using public transportation such as trains, buses, and public transportation that are unnecessary, and as much as possible avoid rush hour when traveling, work from home whenever possible, mass gatherings are prohibited in crowded places and public facilities, avoid gathering with friends and family, including visiting or meeting face-to-face and postponing joint activities, just contact them using phone, internet and other social media, use telephone and other online services to contact a doctor or other facility, and if you feel sick, it is forbidden to visit parents or other elderly people, or if you stay live with them, as much as possible avoid direct interaction with them.

The role of adults in children is important so that children understand and implement policies related to social distancing. In developmental psychology to understand a concept based on age-appropriate cognitive development. In addition to understanding concepts, children need to learn about why it is necessary to implement rules or what is called moral reasoning. At this stage of moral development Piaget explains how children's moral reasoning is also influenced by cognitive abilities. At an early age children will understand, and implement the rules imposed by adults and realize the consequences if they break the rules. In late childhood, children begin to realize that rules can be changed. implement the advice from the government so that the spread of the Covid-19 virus can be controlled. So that people can implement the rules, there needs to be an understanding of the concept and application of social distancing during a pandemic. Not only adults but children also need to understand and implement social distancing policies. An understanding of the rules in social distancing needs to pay attention to the stage of cognitive development. In cognitive development, according to Piaget, early children are in the preoperational and concrete operational stages. In early children, understanding the rules of social distancing involves the role of adults in recognizing the consequences of rules related to social distancing (Santrock, 2011).

Moral's contain values that underlie a person's behavior and must be obeyed or can be related to right or wrong in human behavior. Piaget believed that children's moral ideas develop gradually, where children will create their own world concept in line with sociological theory, where this theory states that the human (moral) world is a world that must be formed by itself. In this case, families and teachers have a very important role as role models for children to shape their moral character and ethics. In this case, moral reasoning also plays an important role in determining the behavior of children. (Setiono, 2009) states that moral reasoning is not something good or bad but how someone comes to a decision that something is good or bad. This means that moral reasoning is a reason or consideration why something is considered good or bad.

Children are individuals who are experiencing a very rapid growth and development process. This can be referred to as the golden age or golden age, which is an era that is very valuable compared to the following ages. According to Anderson et. all, (2003) my childhood is a golden age and will never return, this age will also determine his future life. Although childhood only lasts a short time, it is this age that will determine maturity. The situation caused by the pandemic is expected to be very exhausting for parents, changes in parenting behavior can in turn cause children problems (Grant KE, Compass BE, Stuhlmacher AF, Thurm AE, McMahon SD, Halpert JA (2003), PThe role of adults is basically undeniable in this case because it plays an important role in the growth and development of children, Hurlock (2000), states that the treatment of parents to children will affect the attitudes and behavior of children. The conditions of parenting and communication in the family, especially parents, have a positive or negative influence on children's development. (Kurniati, Alfaeni \& Andriani, 2020) to create a safe and comfortable environment, parents need to bond with their children.

In previous research that discussed the religious and moral development of elementary school-aged children, it was found that there was a role for parents in guiding children while studying at home during the Covid-19 period. Parents try their best so that their children's morals continue to develop while studying at home. This study discusses the moral development of children during the Covid-19 pandemic. The rules set by the government regarding social distancing are then also applied by adults who are still caring for children aged 0-12 years. Based on this, children's morals will be more freely controlled by adults who apply social distancing rules. This study aims to find out more about the stages of moral development in children during the Covid-19 pandemic.

To answer this question, inaccurate research data is needed to find the reader that the results presented are correct, so a method is needed in this study. The research method uses a questionnaire instrument technique, with a quantitative approach and descriptive data analysis. Filling out the questionnaire or questionnaire is done indirectly because the filling is done by the child's parents or siblings. In the questionnaire, respondents will be given 10 questions related to the moral development of children during the Covid-19 pandemic and must answer 10 questions. The purpose of writing this article is to provide some results from research that can make it easier for readers or can be used for further research.

\section{THEORITICAL FRAMEWORK}

Gazzaniga et. al (2015) explains that morality has an important role in human life, because it affects consequences and actions. Moral reasoning involves cognitive processes and develops moral emotions. According to Santrock (2011) Jean Piaget's theory of moral development is called structural-cognitive theory, this theory focuses on attitudes, feelings (influences), and individual cognition of the rules in question. In his book entitled The moral judgment of the child Piaget divides moral development into 3 stages: 1) Pre Moral (ages 4 to 7 years). At this stage the child does not / does not feel obliged to obey the rules; 2) Heteronomous morality (ages 7 to 10 years). At 
this stage of moral development, children see rules as an authority possessed by God, parents, and teachers, which cannot be changed, and must be obeyed as well as possible, and 3) Morality of Autonomous Cooperation (11 years and over). Morals grow through the realization that people can choose different views of moral action. This experience will grow into a basis for assessing the child's behavior. In later development, the child tries to resolve the conflict in the most beneficial way and begins to apply the standard of justice to others.

\section{RESEARCH METHODOLOGY}

This study uses quantitative methods, namely research in the form of data analysis in the form of numbers and processed using statistical methods.

Research Subjects and Research Objects

Participants in this study were someone who had children or siblings aged 0-12 years, totaling 104 people (31 parents and 73 siblings). The research location was conducted in the area of Banyumas Raya and Cirebon City, West Java.

Data collection technique

The method of data collection is in the form of a questionnaire containing 10 questions in the form of a google form, in an open and closed form. Researchers make their own measuring tools by referring to two aspects of moral development according to the stages of age development, namely the Heteronomous stage, Autonomous morality. Questions must be answered by respondents who have met the research criteria. The questions asked were related to the moral development of children during the Covid-19 pandemic and were filled out by research respondents, namely the child's parents or siblings. Respondents answered questions by choosing the options provided and based on the respondent's opinion. Dissemination of questionnaires through social media in the form of WhatsApp.

Data analysis technique

The data analysis method is in the form of descriptive analysis, namely analysis by analyzing data that has been collected from google form by grouping answers and analyzing data descriptively.

Research variable

The variable in this study is the moral development of children and focuses on the process of moral formation of social distancing rules during the Covid-19 pandemic by including the role of adults in this case, namely siblings or parents.

\section{RESULTS AND DISCUSSION}

This research was conducted for 4 days, starting from 13-16 May 2021 during the Covid-19 pandemic, parents or closest relatives want the best for their child's growth and development. Government regulations make the rapid rate of spread of Covid-19 one of the reasons parents or closest relatives of children take advantage of this.

One of the government regulations regarding social distancing. Regarding parents or nuclear families who apply these regulations or not, it will also affect the moral development of children during the Covid-19 pandemic. The following are the results of research related to the attitude of adults around children regarding social distancing rules.

Table 1. Adult Attitudes Regarding Covid-19

\begin{tabular}{|c|c|c|c|}
\hline Number & Social Distance Rules & $\begin{array}{ll}\text { Number } & \text { of } \\
\text { Respondents }\end{array}$ & Percentage \\
\hline 1. & Create social distancing rules & 78 people & $75 \%$ \\
\hline
\end{tabular}

Based on research related to the attitudes of adults around children regarding social distancing rules, it was found that $75 \%$ of parents/children make regulations related to social distancing, while $25 \%$ do not make related regulations. The meaning of social distancing rules for children is not playing outside the house with their peers. Realize that every rule made by adults will have its own consequences for children.

Attitudes or actions taken by adults around children will greatly affect the moral development of children. As mentioned in a study that a child's moral development is influenced by a small environment, the family plays a large role. When entering school age children will follow the rules followed by certain reasons.

With the rules of social distancing, it can train the discipline of the child. Discipline can help children get a limit to correct behavior that is not in accordance with the norm. Discipline can also encourage, guide, and help children to get a feeling of satisfaction because of loyalty and obedience and teach children how to think regularly (Anonymous, 2003). Goodman \& Gurian (2003) suggest that the specific purpose of discipline in children is the formation of the basics of social behavior as expected by society and help develop children's self-control from an early age. In addition, several other objectives of the application of discipline include: a) Forming children's behavior in accordance with norms, b) Playing a role in child development, such as some of their important needs.

Table 2. Adult Attitudes Regarding Social Distancing Rules

\begin{tabular}{lll}
\hline Number & Displayed Attitude & Percentage \\
\hline 1. & Give an explanation & $60.6 \%$ \\
2. & Doing simple games that can be done at home & $25 \%$ \\
3. & Giving gifts & $3.8 \%$ \\
\hline
\end{tabular}

Proceedings homepage: https://conferenceproceedings.ump.ac.id/index.php/pssh/issue/view/7 


$4 . \quad$ Another $10.6 \%$

Based on the research above, it can be seen that adults have a very important role in the process of children's moral development to obey the rules made by their environment to build good moral ethics. As many as $60.6 \%$ of adults provide an understanding that aims so that children do not misunderstand the existence of this social distancing rule. Giving understanding slowly by adults can make children understand more about the purpose of the rules that have been made. Then, as many as $25 \%$ of respondents chose another route so that children get used to the rules applied by playing games at home.

This has to do with discipline between adults and children. Based on previous research, it is explained that in this case discipline is the main key because it is one of the supporting factors for moral behavior. As proof that the child loves the adults around him, the child will not do anything wrong.

In the results of this study, there are several attitudes shown by adults regarding violations or disobedience of children to the social distancing rules applied. All respondents answered how to advise children to more easily understand what adults are saying. In this study, it was stated that children with the application of social distancing rules were invited to play more physical games such as training them during the pandemic so they would not be bored and stressed.

Table 3. Adults' Attitudes towards Social Distancing Compliance

\begin{tabular}{lll}
\hline Number & Attitude & Percentage \\
\hline 1. & Tell them slowly & $87.5 \%$ \\
2. & Force them & $3.8 \%$ \\
3. & Give an example and get used to & $1 \%$ \\
& it & $7.7 \%$ \\
\hline
\end{tabular}

Based on the results of the research above, it can be seen that adults tend to slowly tell children about social distancing rules so that they can easily understand the meaning of these rules. While a small number of others insisted, set an example, and prepared themselves. This is very important because there are still many adults who believe that guiding children is enough to provide understanding without having to set an example. According to Kurniati, Alfaeni and Andriani (2020), parents tend to feel worried about their children's health, therefore (Graha, 2007) states that when teaching the application of healthy living, parents need to set an example of a healthy, neat life and always maintain protocol as a form of educating children.

Basically, children learn from what they see through other people around them. The greater the value given to the child as an observer, the more likely the behavior will be absorbed by the child. This is in accordance with Skinner's theory which states that organisms emit responses, which are gradually shaped by consequences. He said that by giving positive rewards, a behavior will be grown and developed (Sobur, 2013). Conversely, if what is given is a negative reward, then a behavior will be inhibited. (Setyorini \& Kurnaedi, 2018).

In the results of this study, it can be seen how the moral development of children during the Covid-19 pandemic can be influenced by the attitudes shown by the adults around them. Moral is basically ethical behavior that follows the norms in everyday life. If the observed behavior is not commendable, then the child will easily imitate the behavior. Vice versa, commendable behavior will receive appropriate feedback.

Table 4. Children's Ability to Solve Problems During the Covid-19 Pandemic

The following are the results of research that has been conducted on adult beliefs about children's problemsolving abilities:

\begin{tabular}{|c|c|c|c|c|c|}
\hline Number & Agree Disagree & $\begin{array}{l}\text { Average } \\
\text { Children }\end{array}$ & Age of & $\begin{array}{l}\text { Number } \\
\text { Respondents }\end{array}$ & Percentage \\
\hline 1. & Agree & $3-12$ years & & 52 people & $50 \%$ \\
\hline 2. & Do not agree & $2-12$ years & & 52 people & $50 \%$ \\
\hline
\end{tabular}

Based on the results of the research above, it can be seen that between the choices agree and disagree with adults on children's ability to solve problems, produce balanced results. The analysis obtained on the agreed answer items resulted in an average age of 5 and 12 years old who could solve the problem, while on the disagreed answer item the average age of children who could not solve the problem was 2, 3, and 10 years.

This is different from the stages of moral development based on his theory because it can be seen that according to the stages of moral development of Jean Piaget aged 9 to more than 10 years, children begin to consider the goals and consequences of the social distancing rules that are applied. has been created by adults which then children will be able to solve problems. that. alone. Basically, children still have unstable emotions or egocentrism, so solving this problem is the beginning of the child's journey to the adolescent level.

Some respondents who are inconsistent in answering questions in the questionnaire are caused by external and internal factors. External factors are situation, place, and time, while internal factors are individual understanding, concentration, and mood.

\section{CONCLUSION}

The Covid-19 pandemic can have various negative impacts on children in the short, medium and long term, although children infected with Covid-19 have mild symptoms and lower mortality rates than other age groups. Social distancing is one of the steps to prevent and control the corona virus infection, namely by encouraging 
healthy people to limit visits to crowded places and direct contact with other people.

Based on the results of the study, there are several ways that respondents who act as adults must do so that children comply with the social distancing rules given, such as giving advice. One of the things that can make children unable to obey the rules that have been made according to Jean Piaget, is because children are still in the pre-moral stage and have not yet reached the stage of Heteronomous and Autonomous Cooperation moral development, where children feel they have no obligation to obey the rules around them. In addition, from the survey results, some respondents believe that their children/sisters have been able to solve their own problems. Judging from the theory that has been put forward by Jean Piaget.

Based on Piaget's theory of moral development, the role of adults helps children to construct knowledge about morals, such as right or wrong actions. Adults also need to understand how to help conceptualize the right concepts in the context of social distancing. Adult efforts such as explaining rules and giving examples are in accordance with the stage of cognitive development in the pre-operational stage of moral development, and concrete operational. However, in this study only $1 \%$ of people did. This means that most adults do not understand cognitively how to instill a moral understanding related to social distancing in children.

Basically, morals are ethical behavior in everyday life. As explained in this study, adults who provide social distancing rules do not fully try to help children understand the morals related to social distancing rules to children. According to Bandura's theory, children will imitate whatever is done by others, especially the adults around them. 
REFERENCES

BNPB. (2020). Pedoman Penanganan Cepat Medis dan Kesehatan Masyarakat Covid-19 di Indonesia. 23 Maret, 1-38. http://www.covid19.go.id

Christner, N., Essler, S., Hazzam, A., \& Paulus, M. (2021). Children's psychological well-being and problem behavior during the COVID-19 pandemic: An online study during the lockdown period in Germany. PloS One, 16(6), e0253473. https://doi.org/10.1371/journal.pone.0253473

Dewi, P. A. S. C., \& Khotimah, H. (2020). Pola Asuh Orang Tua Pada Anak Di Masa Pandemi Covid-19. Seminar Nasional Sistem Informasi, 2433-2441.

Farihen. (2012). Implikasi Penerapan Teori Perkembangan Moral Jean Piaget dalam Pendidikan Moral Anak ( Suatu Telaah Kritis dalam Perspektif Islam ). Jurnal Teknodik, XVI(2), 1-15.

Gazzaniga, Heaterthon, Halpern (2016). Psychological Science. United States of America: W.W Norton \& Company Inc.

Khiyarusoleh, U. (2016). Konsep Dasar Perkembangan Kognitif Pada Anak Menurut Jean Piaget. Dialektika Jurusan $P G S D, 5(1), 1-10$.

Muniroh, S. M. (2015). Perkembangan Moral Santri Anak Usia Dini. Jurnal Penelitian, $12(2), 180$. https://doi.org/10.28918/jupe.v12i2.649

Prajitno, S. B. (2008). Pengetahuan, metode ilmiah, dan teori. Jurnal Penelitian Publik, 1-29.

Rohayati, T. (2018). Pengembangan Perilaku Sosial Anak Usia Dini. Cakrawala Dini: Jurnal Pendidikan Anak Usia Dini, 4(2), 131-137. https://doi.org/10.17509/cd.v4i2.10392

Santrock, J. (2011). Life Span Development Edisi 13. New York : McGraw Hill.

Secara variatif, R., Anak, P., Kelompok, B., \& Erawati, E. (2018). Meningkatkan kedisiplinan anak melalui penggunaan. 3(1), 36-43.

Sejati, Y. G., Wati, I., \& Fajriyah, N. (2020). Menjaga Stabilitas Mental Anak di Masa Pandemi Covid-19 melalui Aktivitas Bincang Asyik. Jurnal Golden Age, 04(2), 282-289.

Setyorini, W. W., \& Kurnaedi, N. (2018). Pentingnya Figur Orang Tua dalam Pengasuhan Anak. Penguatan Keluarga Di Zaman Now, 139-144.

Wahidah, I., Athallah, R., Hartono, N. F. S., Rafqie, M. C. A., \& Septiadi, M. A. (2020). Pandemik COVID-19: Analisis Perencanaan Pemerintah dan Masyarakat dalam Berbagai Upaya Pencegahan. Jurnal Manajemen Dan Organisasi, 11(3), 179-188. https://doi.org/10.29244/jmo.v11i3.31695

Wijayanti, D. (2010). Perkembangan Moral Siswa Sekolah Dasar. Trihayu: Jurnal Pendidikan Ke-SD-An., $2,83-92$.

Yanizon, A. (2016). Peran Orang Tua dalam Pembentukkan Moral Anak. Jurnal Pendidikan, 3, 1-11.

Yuliana, L. (2015). Penanaman Nilai-Nilai Moral Pada Anak Usia Dini. Jurnal Ilmiah WUNY, 15(1), 1-10. https://doi.org/10.21831/jwuny.v15i1.3527.

Yuniarrahmah, E., \& Rachmah, D. N. (2014). Pola Asuh Dan Penalaran Moral Pada Remaja Yang Sekolah Di Madrasah Dan Sekolah Umum Di Banjarmasin Parenting and Moral Reasoning of Adolescent in Madrasah and Public School in Banjarmasin. Jurnal Ecopsy, 1, 43-50. 